\title{
ARTYKULY
}

Klio. Czasopismo poświęcone dziejom Polski i powszechnym

PL ISSN 1643-8191, t. 54 (3)/2020, s. 51-82

(c) (1) $\Theta$

\author{
AdAm KuCharshi ${ }^{*}$ \\ AgNiesZKa WieCZOREK ${ }^{* *}$
}

\section{Kontakty listowne i kręgi korespondencyjne w podróżach edukacyjnych Rzewuskich na Podhorcach i Rozdole w XVIII w. Epistolograficzny rekonesans badawczy}

\section{Epistolary contacts and correspondence circles in educational trips of the Rzewuski family in Podhorce and Rozdole in the $18^{\text {th }}$ century The epistolographic research reconnaissance}

Streszczenie: Bogactwo źródeł historycznych wytworzonych w związku z podróżami edukacyjnymi reprezentantów rodziny Rzewuskich z linii na Podhorcach i Rozdole w XVIII w.

Instytut Historii i Archiwistyki Uniwersytetu Mikołaja Kopernika w Toruniu, ul. W. Bojarskiego 1, 87-100 Toruń, akr88@umk.pl, ORCID: 0000-0003-4444-7704.

** Instytut Historii i Archiwistyki Uniwersytetu Mikołaja Kopernika w Toruniu, ul. W. Bojarskiego 1, 87-100 Toruń, akraj@umk.pl, ORCID: 0000-0002-0091-596X. 
pozwala na prowadzenie badań nad różnorodnymi zagadnieniami. Wydaje się konieczne przeprowadzenie analizy najobfitszego typu źródła, jakimi są listy z podróży. Pozwala to na ustalenie sieci kontaktów nawiązywanych przez podróżników. Do tego celu idealnie nadaje się koncepcja kręgów korespondencyjnych, która umożliwia nam umiejscowienie podróżujących po Europie Rzewuskich w szerszej perspektywie. Dzięki temu można lepiej scharakteryzować różne wymiary ich podróży: edukacyjny, towarzyski, rodzinny, finansowy, a nawet polityczny.

Abstract: The abundance of historical sources created in connection with educational trips of the Rzewuski family originating from the family line from Podhorce and Rozdó in the $18^{\text {th }}$ century makes it possible to conduct research on diversified issued. It seems necessary to analyse the most abundant source, namely letters written during trips. Such an analysis will allow for establishment of a network of contacts made by the travellers. The concept of correspondence circles seems to be ideal for this purpose, as it makes it possible for us to place the Rzewuski family members travelling around Europe in a wider perspective. This, in turn, results in better descriptions of various dimensions of their trips, including educational, social, family-related, financial and even political dimensions.

Słowa kluczowe: Rzewuscy, kręgi korespondencyjne, korespondencja, podróże edukacyjne, Podhorce, Rozdół

Keywords: the Rzewuski family, correspondence circles, correspondence, educational trips, Podhorce, Rozdół

Dodejmowane w ostatnich latach badania staropolskich podróży edu1 kacyjnych ujawniają wielkie bogactwo źródeł do ich dziejów i spory potencjał analityczny ${ }^{1}$. Niewątpliwie wśród polskich rodzin magnackich wysyłających swoich synów w zagraniczne wojaże kształcące wyróżniają się Rzewuscy, zarówno pod względem częstotliwości, jak i obszernej dokumentacji epistolograficznej tych wyjazdów. Dlatego celem poniższego artykułu jest przedstawienie i krótka charakterystyka zwartego korpusu listów powstałych w związku z podróżami edukacyjnymi przedstawicieli kolejnych

1 Zob. Źródta do dziejów staropolskich podróży edukacyjnych, red. D. Żołądź-Strzelczyk, M. E. Kowalczyk, Wrocław 2017; B. Popiołek, Podróże edukacyjne i poznawcze w źródtach czasów saskich, w: Polski „Grand Tour” w XVIII i poczatkach XIX wieku, red. A. Roćko, Warszawa 2014, s. 45-64. 
pokoleń rodziny Rzewuskich w XVIII w. Traktujemy to jako podsumowanie aktualnego stanu badań i przeprowadzonych kwerend, a jednocześnie programowo jako wstęp do pogłębionej analizy problemu. Z tym zadaniem jest genetycznie związane prześledzenie frekwencji i charakteru obecności Rzewuskich oraz osób towarzyszących im w trakcie podróży, w tym głównie guwernerów, w nieformalnych strukturach informacyjno-komunikacyjnych kreowanych przez procesy wymiany listów. Będzie to w istocie próba nakreślenia zasięgu kręgów korespondencyjnych wytworzonych w obydwu liniach rodziny Rzewuskich w związku z organizowaniem i przebiegiem podróży edukacyjnych ich członków. Warto wykorzystać to poręczne narzędzie analityczne stosowane w badaniach procesów komunikacji społecznej, podróży i przepływu informacji już od kilkudziesięciu lat ${ }^{2}$.

Przystępując do omówienia korespondencji podróżnej Rzewuskich na Podhorcach i Rozdole w XVIII w., mamy na uwadze peregrynacje młodych magnatów przebywających na zachodzie Europy zarówno w pierwszej, jak i drugiej połowie XVIII w. Podejmując ten temat, pragniemy scharakteryzować materiał epistolograficzny trzech pokoleń, a przy tym dwóch linii magnackiej rodziny Rzewuskich - na Podhorcach i Rozdole. Istotne dla tego zagadnienia będą zagraniczne podróże edukacyjne - które łączy ciągłość pokoleniowa - jakie odbywali Rzewuscy z linii na Podhorcach w latach 20. - Seweryn Józef (zm. 1754) i Wacław Piotr (1706-1779), synowie hetmana wielkiego koronnego, twórcy rodowej potęgi Stanisława Mateusza Rzewuskiego (1662-1728), w latach 50. zaś Józef (1739-1816) i Stanisław (1737-1786) oraz Seweryn (1743-1811) - synowie wspomnianego wcześniej Wacława Rzewuskiego. Przedmiotem naszych rozważań będzie również materiał epistolograficzny stanowiący pokłosie wojaży zagranicznych młodych magnatów z linii Rzewuskich na Rozdole, jakie odbywali w latach 40. i w drugiej połowie lat 60. XVIII w., synowie Michała Józefa Rzewuskiego - Franciszek (ok. 1730-1800), Jan (zm. 1759), Adam (zm. 1776) i Kazimierz (1750-1820).

2 Szerzej na temat kręgów korespondencyjnych zob. J. Wojtowicz, Ze studiów nad tzw. kręgiem korespondencyjnym. Zatożenia - badania - postulaty, w: Rozprawy z dziejów XVIII wieku. Z dziejów komunikacji socjalnej epoki nowożytnej, red. J. Wojtowicz, Toruń 1993, s. 23-31. 
Przy okazji omawiania korespondencji z podróży edukacyjnych Rzewuskich z linii na Podhorcach należy zauważyć, że wpływ na powstanie obszernego materiału epistolograficznego miała bez wątpienia magnacka pozycja tego rodu. Warto tylko wspomnieć, że jego członkowie dostępowali ważnych urzędów w Rzeczypospolitej, a dwóch z nich pełniło funkcje zarówno hetmana wielkiego koronnego, jak i hetmana polnego koronnego. Linia hetmańska została zapoczątkowana przez Stanisława Mateusza Rzewuskiego, który jako pierwszy otrzymał w 1726 r. buławę wielką koronną (hetmanem polnym został w 1706 r.), następnie uzyskał ją jego młodszy syn Wacław (1773-1774) (hetmanem polnym koronnym został w 1752 r.) $)^{3}$. Również jego syn - Seweryn, był hetmanem polnym koronnym w latach $1774-1795^{4}$.

Badania prowadzone nad zasobem archiwaliów Rzewuskich linii podhoreckiej wskazują na bogate zbiory. W czasach Stanisława Mateusza Rzewuskiego archiwum rodzinne znajdowało się w Rejowcu, a w ostatnich latach jego życia archiwalia gromadzono również w Podhorcach. Zdaniem badaczy taką hipotezę potwierdza niewielki zasób materiałów rodzinnych po hetmanie, jaki zachował się w podhoreckim archiwum. W późniejszych latach młodszy syn hetmana Wacław powiększył zbiory podhoreckie o cenniejsze archiwalia z Oleska, należące wcześniej do jego brata Seweryna Józefa. Po śmierci Wacława opiekę nad archiwaliami Rzewuskich przejął jego najmłodszy syn - Seweryn ${ }^{5}$.

Stan naszej wiedzy o podróżach edukacyjnych synów Stanisława Mateusza Rzewuskiego - Seweryna Józefa (1720-1723) i Wacława (1724-1727), po europejskich krajach określają zarówno rezultaty dotychczasowych badań ${ }^{6}$, jak i zebrany w ich wyniku materiał źródłowy. W obję-

3 A. Link-Lenczowski, Rzewuski Stanistaw Mateusz h. Krzywda, w: Polski stownik biograficzny (dalej: PSB), t. 34, red. H. Markiewicz, Wrocław-Warszawa-Kraków 1992, s. 154, 158; Z. Zielińska, Rzewuski Wactaw h. Krzywda, w: ibidem, s. 171, 176.

4 Z. Zielińska, Rzewuski Seweryn h. Krzywda, w: ibidem, s. 140.

5 Za: K. Syta, Archiwa magnackie w XVIII wieku. Studium kultury kancelaryjno-archiwalnej, Toruń 2010, s. 243.

6 W dotychczasowej literaturze materiały dotyczące tej peregrynacji były przedmiotem badań: Z. Zielińska, Rzewuski Wactaw..., s. 169; M. Chachaj, Orszak magnata odbywającego podróż edukacyjna (wiek XVI-XVIII), w: Patron i dwór. Magnateria Rzeczypospolitej 
tych kwerendą archiwach i bibliotekach znaleziono bogate i interesujące zbiory epistolograficzne ${ }^{7}$. Pierwsza kolekcja listów z podróży edukacyjnej Rzewuskich na Podhorcach obejmuje lata 1720-1723 oraz 1725-1726. Jest ona jednak rozproszona i występuje przede wszystkim w postaci kopii $^{8}$. Te dwa czynniki mają niewątpliwie wpływ na proces dokumentowa-

w XVI-XVIII wieku, red. E. Dubas-Urwanowicz, J. Urwanowicz, Warszawa 2006, s. 170; A. Markiewicz, Podróże edukacyjne w czasach Jana III Sobieskiego. Peregrinationes Jablonovianae, Warszawa 2011, s. 48 i nast.; A. Kucharski, „Theatrum peregrinandi”. Poznawcze aspekty staropolskich podróży w epoce późnego baroku, Toruń 2013, s. 93-94 i nast.; A. Wieczorek, W „drodze paryskiej”-podróże edukacyjne Seweryna Józefa $i$ Wactawa Rzewuskich wlatach dwudziestych XVIII wieku, w: Studiazdziejówedukacji w Rzeczypospolitej Obojga Narodów Korony i Litwy, red. K. Puchowski, J. Orzeł, Warszawa 2019, s. 143-177; A. Kucharski, S. Roszak, A. Wieczorek, O podróżach edukacyjnych w XVII i XVIII wieku: przypadek Rzewuskich, w: Spoteczne i kulturowe uwarunkowania edukacji Rzeczypospolitej XVI-XVIII wieku, cz. 1, red. K. Puchowski, wstęp i oprac. J. Orzeł, Warszawa 2017, s. 75-97; eidem, Guwernerzy Rzewuskich na Podhorcach w XVII-XVIII wieku - szkic do portretu, w: Spoteczne i kulturowe uwarunkowania edukacji Rzeczypospolitej XVI-XVIII wieku, cz. 2, red. K. Puchowski, wstęp i oprac. J. Orzeł, Warszawa 2018, s. 149-183.

Ze względu na rozproszenie pierwszej kolekcji korespondencji warto wskazać miejsca, w których jest ona przechowywana. Ten wykaz zasobów był już wcześniej prezentowany (zob. A. Wieczorek, op. cit., s. 148-149), teraz jednak stanowi uzupełnienie o nowe zbiory pozyskane $\mathrm{w}$ czasie prowadzonych badań. Aktualnie dysponujemy materiałem epistolograficznym znajdującym się w zbiorach pochodzących z zasobów bibliotecznych Biblioteki Jagiellońskiej w Krakowie (dalej: BJ) (rps 5269), Biblioteki Książąt Czartoryskich w Krakowie (dalej: BCzart.) (rps 558 IV, 562 IV, 2171 IV, 2448 IV), Biblioteki Uniwersyteckiej w Warszawie (rps 92), Biblioteki Narodowej w Warszawie (dalej: BN) (rps 12387 III, akc. 1968), Biblioteki Zakładu Narodowego im. Ossolińskich we Wrocławiu (dalej: BOssol.) (rps 27 II, 2891 II, 5173 I, Pawlik 210), Biblioteki Kórnickiej Polskiej Akademii Nauk (dalej: BK PAN) (rps 423) oraz archiwalnych - Archiwum Państwowego w Lublinie (dalej: APL) (Akta dóbr Staw i Horodyszcze, rps 93), Archiwum Narodowego w Krakowie (oddział na Wawelu) (dalej: ANK), Archiwum Podhoreckie (dalej: APodh.) (rps II 196) oraz Archiwum Głównego Akt Dawnych w Warszawie (dalej: AGAD), Archiwum Radziwiłłów (dalej: AR), dz. V, nr 13655. Spośród bibliotek zagranicznych na uwagę zasługuje Lwiwska Nacjonalna Naukowa Biblioteka Ukrajiny imeni Wasyla Stefanyka we Lwowie (dalej: LNNBU) (Zbiór Biblioteki Ossolineum, rps 1311, f. 5, op. 1).

8 Zachowana korespondencja podróżna w postaci kopii może tłumaczyć brzmienie tytułów niektórych listów adresowanych do Seweryna Józefa jako starosty chełmskiego: Copia listu tegoż JWPa[na] Rzewuskiego wojewody podl[askiego] het[mana] pol[nego] 
nia archiwaliów. Jeśli chodzi o korespondencję zachowaną w postaci kopii, rodzą się wątpliwości co do kompletności i stanu zachowania materiału rękopiśmiennego. Ze względu na wspomniane jego rozproszenie miejscem przechowywania korespondencji są różnorodne zbiory listów. Znaczna ich większość jest nam znana z kopiariuszy korespondencji Stanisława Mateusza Rzewuskiego, co może świadczyć o wadze jego listów dla historii Rzeczypospolitej w początkach XVIII w. Znajdują się one między listami adresowanymi m.in. do kanclerza wielkiego koronnego Jana Sebastiana Szembeka, marszałka wielkiego koronnego Józefa Wandalina Mniszcha, a także wśród korespondencji adresowanej do Stanisława Mateusza, której autorami byli m.in. kasztelan krakowski Adam Mikołaj Sieniawski czy wojewoda krakowski Janusz Antoni Wiśniowiecki. Pozostałe możemy znaleźć m.in. w kopiariuszach korespondencji wspomnianego już marszałka wielkiego koronnego Józefa Wandalina Mniszcha ${ }^{10}$ czy kopiariuszach różnych listów z XVIII w. Zgoła odmiennym zasobem korespondencji podróżnej z peregrynacji Seweryna Józefa Rzewuskiego są listy pochodzące ze zbiorów archiwum rodzinnego znajdującego się w Archiwum Narodowym w Krakowie (Archiwum Podhoreckie, rps II 196). O ile stanowią one zwarty materiał epistolograficzny, o tyle są zbiorem luźnych listów, co istotne -

kor[onnego] do syna swego starszego WJPa[na] Seweryna Rzewuskiego starosty chetmskiego w cudzych krajach będącego pisanego z Lubomla; BJ, rps 5269, k. 49v-51: Stanisław Mateusz Rzewuski do Seweryna Józefa Rzewuskiego, Luboml, 30 I 1722. Seweryn Józef Rzewuski został starostą chełmskim już po powrocie z podróży edukacyjnej (1723-1736); zob. Urzędnicy centralni i nadworni Polski XIV-XVIII wieku, oprac. K. Chłapowski et al., red. A. Gąsiorowski, Kórnik 1992, s. 104, nr 601, s. 201.

9 Wystarczy wskazać chociażby: BCzart., rps 2448 IV, gdzie zbiór nosi nazwę Kopiariusz korespondencji Stanistawa Mateusza Rzewuskiego, hetmana polnego koronnego, $z$ lat 1721-1722, listów, manifestów, i mów prymasa Teodora Potockiego i in. oraz pism politycznych $i$ wierszy z lat 1732-1737 i 1744-1745, czy BCzart., rps 2171 IV o tytule Korespondencja Mateusza Stanistawa Rzewuskiego, wojewody podlaskiego i hetmana polnego koronnego, jego syna Seweryna, prymasa Teodora Potockiego, Stefana Potockiego, referendarza koronnego $i$ in. z lat 1721-1725. Wskazane kopiariusze w większości mają charakter zbiorów silva rerum lub miscellaneów.

10 Mowa tutaj o BOssol., rps 27 II. Zbiór nosi nazwę Listy Józefa Mniszka [Mniszcha], marszatka wielkiego koronnego do Stanistawa Mateusza Rzewuskiego, wojewody podlaskiego... i inne. 
nieadresowanych, stąd też trudno precyzyjnie określić, do kogo były skierowane. Identyfikację utrudnia brak zarówno informacji o adresacie, jak i adnotacji co do miejsca i czasu ich powstania. W jednym z nich autor wskazał na Paryż jako miejsce nadania listu pisanego 2 kwietnia 1721 r., co zresztą potwierdzają wcześniejsze ustalenia świadczące o pobycie Seweryna Józefa w tym czasie w stolicy Francji ${ }^{11}$. Bez wątpienia jest to materiał unikatowy, wyróżniający się spośród znanego nam zbioru korespondencji. Jego wstępny ogląd pozwala stwierdzić, że mógł to być notatnik Seweryna Józefa. Świadczą o tym poprawki i skreślenia znajdujące się w tekście. Sama forma notesu może wskazywać na wprawkę do pisania listów w języku francuskim. Niewykluczone, że był to materiał do sprawdzenia przez wynajętego nauczyciela języka francuskiego.

Aktualnie nam znany materiał epistolograficzny jest również podstawą naszej wiedzy o czasie, w jakim synowie hetmana odbywali podróże edukacyjne. Mając na uwadze okres, w którym Rzewuscy z linii na Podhorcach wojażowali, a więc lata 1720-1723 i 1724-1727, należy zauważyć, że istnieje luka chronologiczna obejmująca lata 1724 i 1727 . Dotyczy ona tym samym pierwszego i ostatniego roku peregrynacji Wacława Rzewuskiego. Dla omawianego etapu podróży najwcześniejszy znany nam list z jego wojaży datowany jest na styczeń 1725 r., kiedy peregrynant i jego preceptor Marcin Kawiecki byli już za granicą ${ }^{12}$. Ostatni list pochodzi z kolei z 13 grudnia 1726 r., kiedy młodzieniec i guwerner najprawdopodobniej wyjechali już z Paryża i zgodnie z życzeniem hetmana mieli udać się do Rzymu $^{13}$. Na ten moment nie wiemy, jak przebiegała dalsza podróż Wacława. Możemy jedynie przypuszczać, że Rzym stanowił już ostatni jej etap przed powrotem do rodzinnego domu. W odróżnieniu od korespondencji podróżnej Wacława wymiana listów z podróży Seweryna Józefa charakteryzuje się ciągłością lat - od 1720 do 1723.

11 ANK, oddział na Wawelu, APodh., II 196: Księga konceptów korespondencji Seweryna Rzewuskiego z Paryża. Zbiór listów pochodzi z $1721 \mathrm{r}$.

12 BCzart., rps 562 IV, s. 63-65: Stanisław Mateusz Rzewuski do Marcina Kawieckiego, Luboml, 12 I 1725.

13 BCzart., rps 562 IV, s. 489-491: Stanisław Mateusz Rzewuski do Marcina Kawieckiego, Luboml, 13 XII 1726. 
Poza tym należy wskazać na jeszcze jedną charakterystyczną cechę wspomnianego materiału epistolograficznego. Korespondencja podróżna podhoreckich Rzewuskich z lat 20. XVIII w. jest nierównomierna. Znacznie bogatsza ilościowo jest dokumentacja z podróży starszego syna hetmana Seweryna Józefa. Dysponujemy nie tylko większym, ale i bardziej zwartym zasobem listów, co w konsekwencji pozwala na odtworzenie szczegółowego przebiegu podróży edukacyjnej. Potwierdza to regularna korespondencja Stanisława Mateusza Rzewuskiego adresowana do peregrynanta i guwernera. W prezentowanym materiale źródłowym doskwiera jednak niedostatek listów Seweryna Józefa do ojca. Obecnie znane nam są tylko dwa listy, które Seweryn Józef napisał do Stanisława Mateusza w pierwszych miesiącach wojaży (jeden pisany jeszcze z kraju - z Warszawy, drugi już z Paryża) ${ }^{14}$.

W odniesieniu do korespondencji podróżnej młodszego syna - Wacława, trzeba zauważyć, że zachowała się niewielka liczba listów ${ }^{15}$. Przebieg jego podróży edukacyjnej możemy jedynie zrekonstruować na podstawie pojedynczych listów Stanisława Mateusza Rzewuskiego adresowanych zarówno do Wacława, jak i preceptora Kawieckiego. Nieznane nadal pozostają listy peregrynanta i guwernera do ojca. Ten deficyt korespondencji Wacława do ojca możemy jedynie zastąpić listami pisanymi przez hetmana do syna. Niemniej jednak zgromadzony materiał epistolograficzny umożliwia analizę źródłową, chociaż nie tak szczegółową jak w przypadku korespondencji podróżnej starszego brata.

Nasza wiedza o podróżach kolejnego pokolenia Rzewuskich na Podhorcach jest znacznie ograniczona aktualnym stanem badań nad tym tematem. Istotnie stan zachowania korespondencji z okresu peregrynacji edukacyjnych synów Wacława Rzewuskiego, wówczas hetmana polnego koronnego, można określić jako szczątkowy. Obecnie dysponujemy bowiem w zasadzie tylko kilkoma listami podróżnymi z czasu, kiedy to w latach 1755-1757 po Europie wojażowali jego starsi synowie: Józef i Stanisław

14 LNNBU, rps 1311, f. 5, op. 1, k. 174v-175: Seweryn Józef Rzewuski do Stanisława Mateusza Rzewuskiego, Warszawa [s.a.]; LNNBU, rps 1311, f. 5, op. 1, k. 175v-176: Seweryn Józef Rzewuski do Stanisława Mateusza Rzewuskiego, Paryż, 20 II 1721.

15 Korespondencja podróżna Wacława Rzewuskiego pochodzi ze zbiorów Biblioteki Książąt Czartoryskich w Krakowie (rps 562 IV). 
Ferdynand oraz po krótkiej przerwie najmłodszy Seweryn (1759-1761) ${ }^{16}$. Wspólną cechą łączącą te wyjazdy była postać ich opiekuna, którym został francuski guwerner Louis-Antoine Caraccioli ${ }^{17}$. Analogicznie prezentuje się również w przypadku obydwu powyższych podróży kwestia nieznajomości listów wymienianych między peregrynantami i domem rodzinnym. Biorąc pod uwagę stałą praktykę komunikacyjno-pocztową staropolskich wojażerów, często kontaktujących się z domem rodzinnym korespondencyjnie, wysoce zasadne wydaje się stwierdzenie, że jakieś listy w trakcie podróży z pewnością musiały powstawać i trafiać w ręce Wacława Rzewuskiego. Świadczy o tym chociażby fakt istnienia późniejszej korespondencji tego typu. Wiadomo, że w rodzinnym archiwum, zgromadzonym niegdyś na zamku w Podhorcach, do dzisiaj przechowywany jest obszerny zbiór korespondencji Wacława do syna Seweryna, w którym najstarsze listy są datowane jednak dopiero na pięć lat po jego powrocie z podróży zagranicznej ${ }^{18}$.

Linia Rzewuskich na Rozdole także wytworzyła materiał epistolograficzny pokaźnych rozmiarów. Według znawców przedmiotu początkowo archiwalia rodzinne były gromadzone w Rozdole. Jednak później nastąpiła ich częściowa relokacja do innych siedzib linii hetmańskiej. Rozdół pozostał natomiast do końca XVIII w. w rękach starszej, rozdolskiej linii tej rodziny magnackiej, wywodzącej się od kasztelana podlaskiego Adama Rzewuskiego (zm. 1717), która wygasła po bezpotomnej śmierci jego wnuka Kazimierza, jej ostatniego męskiego przedstawiciela, w początkach następnego stule$\mathrm{cia}^{19}$. Same dobra rozdolskie, wraz z okazałym pałacem wzniesionym przez Rzewuskich ok. 1740 r., zdobnym wspaniałymi kolekcjami sztuki, przeszły w posiadanie Lanckorońskich w wyniku małżeństwa Ludwiki Rzewuskiej

$16 \mathrm{~W}$ archiwum rodzinnym znajduje się zaledwie jeden list, którego autorstwo jest przypisywane Sewerynowi Rzewuskiemu. Pochodzi on z czasu jego pobytu we Włoszech: ANK, oddział na Wawelu, APodh., XIV-3: Seweryn Rzewuski do Ignazio Vanettiego, Turyn, 20 II 1760. Oprócz tego znane są listy ich guwernera.

17 Więcej o tych wyjazdach zob. A. Kucharski, Instrukcje podróżne Wactawa Rzewuskiego dla synów z potowy XVIII wieku, w: Źródta do dziejów staropolskich podróży edukacyjnych, s. 63-80.

18 ANK, oddział na Wawelu, APodh., II 152. Zbiór nosi nazwę Listy Wactawa Rzewuskiego do syna Wactawa i obejmuje lata 1766-1779.

19 K. Syta, op. cit., s. 242-243. 
z Antonim Józefem Lanckorońskim w $1793 \mathrm{r}^{20} \mathrm{Z}$ tego powodu archiwalia pozostałe po Rzewuskich z Rozdołu wchodzą obecnie w skład lwowskich zbiorów Lanckorońskich. Zawierają one wiele dokumentów wytworzonych w związku z działalnością hetmana polnego koronnego Stanisława Mateusza i jego brata kasztelana podlaskiego Adama Rzewuskiego (zm. 1717), a także potomków tego ostatniego ${ }^{21}$. Wśród nich uwagę zwracają listy Franciszka, wnuka Adama, o którym wiemy, że przebywał za granicą przez blisko trzy lata, ucząc się i poznając takie kraje, jak: Włochy, Francja czy Saksonia ${ }^{22}$. Przebieg tej podróży można dość dokładnie odtworzyć na podstawie jego listów do matki Franciszki z Cetnerów²3.

Kwerenda w rozproszonym materiale źródłowym dotyczącym rodziny Rzewuskich przyniosła także wymierne rezultaty w postaci odnalezienia kolejnych listów. Znacznie poszerzają one dotychczas znany krąg adresatów korespondencji podróżnej Rzewuskich, świadcząc o utrzymywaniu bliskich kontaktów z rodziną Tarłów. Są przechowywane w zasobie Centralnego Państwowego Archiwum Historycznego Ukrainy w Kijowie, w rodzinnym Archiwum Tarłów ${ }^{24}$. W kijowskim archiwum mieści się również stosunkowo niewielkie objętościowo Archiwum Rzewuskich (Fond 259), liczące zaledwie 241 jednostek archiwalnych z lat 1649-1916 $6^{25}$. Znajduje się w nim różnorodny materiał rękopiśmienny. Brak tam natomiast listów z czasów podróży zagranicznych. Jak można wnosić z adresów kopertowych i treści, listy podróżne Rzewuskich były kierowane do wojewody sandomierskiego

20 Rody magnackie Rzeczypospolitej, Warszawa 2009, s. 84.

21 A. Krochmal, Centralne Państwowe Archiwum Historyczne Ukrainy we Lwowie. Przewodnik po zasobie archiwalnym, Warszawa 2005, s. 354-355.

22 S. Roszak, Europejska peregrynacja Franciszka Rzewuskiego z lat 1746-1748 w świetle listów do matki, w: Z badań nad historia, oświata i kultura. Studia ofiarowane Ryszardowi W. Wotoszyńskiemu $w$ siedemdziesiąta rocznice urodzin i czterdziesta piąta pracy naukowej, red. J. Kukulski, Piotrków Trybunalski 2001, s. 411-420.

23 Centralnyj Derżawnyj Istorycznyj Archiw Ukrajiny u Lwowi (dalej: CDIAUL), F. 181 , op. 2, 448 .

24 Centralnyj Derżawnyj Istorycznyj Archiw Ukrajiny, m. Kyjiw (dalej: CDIAUK), F. 254, op. 1, 531 .

${ }_{25}$ T. Ciesielski, Spuścizny rodzinne i archiwa majątkowo-gospodarcze polskiej szlachty w wybranych archiwach ukrainskich, w: Stan badan nad wielokulturowym dziedzictwem dawnej Rzeczypospolitej, t. 2, red. W. Walczak, K. Łopatecki, Białystok 2010, s. 299. 
Jana Tarły. Pochodzą z drugiej połowy lat 40. XVIII w., a ich nadawcami byli podróżujący po Europie trzej synowie wojewody podolskiego Michała Józefa Rzewuskiego: Franciszek, Adam i Jan ${ }^{26}$.

Odrębny zespół stanowią listy z okresu podróży najmłodszego z synów Michała Józefa. Kazimierz Rzewuski, późniejszy pisarz polny koron$\mathrm{ny}^{27}$, z racji dużej różnicy wieku został wysłany w swoją podróż edukacyjną (1766-1768) jako ostatni, aż kilkanaście lat później, po powrocie swoich starszych braci do kraju. Przez ponad dwa lata uczył się i wojażował za granicą (Francja, ziemie niemieckie, Holandia) pod opieką pijarskiego guwernera Aleksego Andrzeja Ożgi. Jego wyjazd kształcący przysporzył rodzicom sporo zmartwień z powodu nie najlepszego prowadzenia się i popadania syna w rozmaite kłopoty. Dramatycznym, a zarazem przełomowym momentem tej podróży był pojedynek, w trakcie którego Kazimierz odniósł poważną ranę. Zmusiło to zarówno jego samego, jak i rodziców do zmiany pierwotnego charakteru podróży i podjęcia decyzji o poddaniu się kuracji ${ }^{28}$. Wskutek tych wydarzeń jego opiekunem w podróży został starszy brat, Franciszek ${ }^{29}$. Był to ostatni ze znanych nam Rzewuskich na Rozdole, który wyruszył w podróż edukacyjną przed upadkiem szlacheckiej Rzeczypospolitej. Nic nie wiadomo również o takich podróżach w gałęzi na Pohrebyszczu, zapoczątkowanej przez Stanisława Ferdynanda Rzewuskiego, który ożenił się w 1758 r., a dwa lata później urodził się jego syn Adam Wawrzyniec ${ }^{30}$.

Podróżne kręgi korespondencyjne, tworzone przez nadawców i adresatów listów, zapewniają wgląd w rozbudowane systemy łączności i wymiany informacji między podróżnikami a ich domami rodzinnymi. W szerszym

26 O podróży edukacyjnej Jana nie było dotąd wiadomości; por. M. Czeppe, Rzewuski Jan h. Krzywda, w: PSB, t. 34, s. 111-112.

27 Zob. o nim szerzej w: Ł. Kądziela, Rzewuski Kazimierz h. Krzywda, w: ibidem, s. $115-116$.

28 Zob. A. Kucharski, Blaski i cienie peregrynacji w cudzych krajach. Podroż edukacyjna Kazimierza Rzewuskiego (1766-1768), „Klio. Czasopismo poświęcone dziejom Polski i powszechnym” 2019, t. 49, s. 61-87; idem, Rodzinne tradycje podróżowania na przyktadzie Franciszka i Kazimierza Rzewuskich, w: Studia z dziejów edukacji w Rzeczypospolitej Obojga Narodów..., s. 179-205.

29 Więcej o osobie Louisa-Antoine'a Caraccioliego zob. A. Kucharski, S. Roszak, A. Wieczorek, Guwernerzy Rzewuskich na Podhorcach w XVII-XVIII wieku..., s. 149-183. 30 T. Zielińska, Poczet polskich rodów arystokratycznych, Warszawa 1997, s. 358-360. 
znaczeniu odnoszą się także do środowisk i osób, z którymi stykali się oni sami lub ich towarzysze podróży. Próby prezentacji kręgów korespondencyjnych, których uczestnikami byli podróżujący Rzewuscy, można dokonać, odwołując się przede wszystkim do dwóch kryteriów: chronologicznego i typologicznego. Przedstawimy zatem w zwięzłej formie kręgi funkcjonujące w obydwu liniach, na Podhorcach i Rozdole, zgodnie z następstwem czasowym podróży oraz rodzajami tych kręgów. Ich typy pozwalają nam wyszczególnić społeczno-indywidualne mechanizmy selekcji, decydujące w głównej mierze o doborze adresatów. W szerszym rozumieniu analizy dokonywane na gruncie badań komunikacji społecznej pozwalają mówić o istnieniu i funkcjonowaniu grup korespondencyjnych, których członkowie byli sobie bliscy z różnych powodów. W obrębie takich grup daje się dodatkowo wyodrębnić różne kręgi korespondencyjne ${ }^{31}$. Podróżników z familii Rzewuskich, z obydwu jej linii, adresujących swoje listy z zagranicy do kraju także należy traktować jako grupę korespondencyjną, w ramach której można pokusić się o wskazanie przynajmniej kilku różnych kręgów korespondencyjnych.

\section{Krąg rodzinno-domowy}

Dominuje on w oczywisty sposób w strukturze epistolograficznych relacji z każdej spośród zaprezentowanych powyżej podróży edukacyjnych. W jego ramach realizuje się też istotny walor emocjonalny w postaci kultywowania zażyłości i podtrzymywania więzi na odległość. W tym kontekście należy zwrócić uwagę na ważną kwestię, mianowicie utrzymywanie łączności z domem rodzinnym przez kontakt korespondencyjny. Wymóg pisania listów do rodziców był często zawarty w treści instrukcji podróżnych. Niestety nie dysponujemy żadnymi instrukcjami edukacyjnymi autorstwa Stanisława Mateusza Rzewuskiego, stąd też trudno odnieść się do takiego zalecenia, jakie hetman zapewne kierował do swoich synów przed peregrynacją. Również preceptor Marcin Kawiecki nie wspominał w instrukcji z ok. 1720 r., pisanej dla udającego się w podróż po Europie Seweryna

31 J. Wojtowicz, op. cit., s. 25. 
Józefa, o przesyłaniu listów do domu rodzinnego ${ }^{32}$. Możemy jedynie założyć, że takie rady i wskazania zostały wypowiedziane ustnie, o czym świadczyłby chociażby ton wypowiedzi hetmana $\mathrm{w}$ listach adresowanych do synów. W jednym z nich, kierowanym do Seweryna Józefa, precyzował swoje oczekiwania: „listów pisanie większy przyniosłoby pożytek, aniżeli romansów czytanie" ${ }^{33}$. Co więcej, hetman nakładał również na preceptora obowiązek informowania go o przebiegu podróży, a każdą zwłokę lub brak nadchodzącej korespondencji wyrażał głębokim niezadowoleniem, podkreślając, że „Nad kilku niedzielnym milczeniem różne miałem myśli, nie odbierając ani od WM Pa[na], ani od syna mego żadnych wiadomości” ${ }^{34}$. Wymóg przesyłania informacji do domu rodzinnego dotyczył również młodszego syna - Wacława, co w sposób szczególny wybrzmiewało w pierwszych słowach jednego z listów wobec braku wiadomości: „Nie mając tak dawno żadnej od ciebie de statu zdrowia i powodzenia Twego wiadomości" ${ }^{35}$. I teraz hetman wymagał od guwernera przesyłania na bieżąco wieści z przebiegu podróży: „Jakom w dawniejszych listach upraszał WM Pana, o częstsze de statu zdrowia, i powodzenia syna mego wiadomości”’36.

Mimo istnienia pojedynczych listów deficyt korespondencji podróżnej synów Wacława Rzewuskiego z połowy XVIII w. jest bardzo dotkliwy. Przynajmniej w niewielkiej mierze ten brak dyskontują znane nam instrukcje podróżne, skreślone piórem Wacława dla każdego z synów z osobna ${ }^{37}$. Wy-

32 Refleksyje do przysztej peregrynacyi Jmć Pana starosty chetmskiego a s.p. Jmć P[ana] wo[jewo]dy wotyński[ego] podane JW Jmć Panu h[etmanowi] w[ielkiemu] k[oronnemu] ojcu jego przez Jmć P [ana] Kawieckiego guwernera tegoż, oprac. A. Markiewicz, w: Przestrogi i nauki dla dzieci. Instrukcje rodzicielskie (XVIII w.), wstępem i objaśnieniami opatrzyły M. E. Kowalczyk, D. Żołądź-Strzelczyk, Wrocław 2017, s. 25-27.

33 BCzart., rps 2448 IV, s. 103: Stanisław Mateusz Rzewuski do Seweryna Józefa Rzewuskiego, [s.l.] 30 I 1722.

34 BCzart., rps 2448 IV, s. 22: Stanisław Mateusz Rzewuski do Marcina Kawieckiego, Łukówek [7 XI 1721].

35 BCzart., rps 562 IV, s. 235: Stanisław Mateusz Rzewuski do Wacława Rzewuskiego, Warszawa [7 III 1726].

36 BCzart., rps 562 IV, s. 72: Stanisław Mateusz Rzewuski do Marcina Kawieckiego, Luboml, 23 II 1725.

37 Instrukcje powstały w latach 1755 i 1759; zob. A. Kucharski, Instrukcje podróżne Wactawa Rzewuskiego dla synów..., s. 63-80. 
syłanie listów do domu rodzinnego przez młodych Rzewuskich potwierdza to, że Wacław Rzewuski nakładał na swego najmłodszego syna obowiązek prowadzenia z nim regularnej korespondencji. W punkcie ósmym swojej instrukcji podróżnej, spisanej w 1759 r. w Podhorcach, precyzował: „Pisywać do mnie raz w miesiąc listki małe bez koperty, świadkowe tylko pisząc zawsze po francusku, i do koperty Jmci Pana Caracciolego dając" ${ }^{38}$. Stanowi to niezbity dowód powstania takich listów, gdyż trudno wyobrazić sobie, aby Seweryn, znany skądinąd z dobrych relacji z ojcem, nie był mu w tym względzie posłuszny i zaniechał kontaktu z domem. Co więcej, listy te, zarówno pod względem treści, jak i samego faktu ich powstawania, miały podlegać kontroli guwernera. Dodatkowo wymóg pisania ich po francusku stanowił zapewne formę sprawdzenia stopnia zaawansowania w nauce tego języka. I takie było chyba główne zamierzenie autora instrukcji, który rzetelnych informacji o postępach w nauce syna i jego zachowaniu oczekiwał bardziej od francuskiego guwernera niż samego Seweryna. O ile wiemy o istnieniu listów, które Caraccioli pisywał do Wacława Rzewuskiego, o tyle „listki” Seweryna dotąd pozostają nieznane.

Podobny wymóg Wacław stawiał wcześniej swemu synowi Józefowi, wyjeżdżającemu za granicę wraz z bratem Stanisławem Ferdynandem, pisząc dla niego na odjezdnym instrukcję podróżną (1755), w której znalazło się następujące zalecenie: „Życzę się aplikować: Primo, aby po francusku pięknie mówić i pisać listy" ${ }^{39}$. Realizacja powyższego nakazu odnosiła się przede wszystkim do opanowania w mowie i piśmie języka francuskiego, a w następnej kolejności rudymentów sztuki epistolarnej. Kolejnym elementem miał być z pewnością informacyjny charakter tych listów. Sporo danych przynosi również katalog wydatków, zestawiany na bieżąco przez francuskiego preceptora. Świadczy on też o jednej istotnej kwestii, szczególnie nas

38 Informacyja synowi memu Sewerynowi do Wiednia $i$ dalszych cudzych krajów jadącemu, dana dnia 14 Februarii Roku Pańskiego 1759 w Podhorcach, oprac. A. Kucharski, w: Przestrogi i nauki dla dzieci..., s. 156.

39 Informacyja synowi memu Józefowi dana w Podhorcach R.P 1755 D. 14 Augusti, oprac. A. Kucharski, w: ibidem, s. 166. 
tutaj interesującej. Caraccioli pisze kilkakrotnie o odbieraniu listów z poczty, a także o tym, że podróżnicy wysyłali je do domu ${ }^{40}$.

Krąg korespondencyjny Rzewuskich na Rozdole podróżujących po Europie, wytyczony przez znane nam ich listy, zamyka się głównie w ścisłych ramach najbliższej rodziny. W latach 40. i 60. XVIII w. Franciszek Rzewuski kierował swoje listy do ojca Michała Józefa oraz matki Franciszki Rzewuskiej z Cetnerów. Szczególnym przypadkiem są właśnie liczne zbiory listów pisanych przez podróżników do matek, rzadziej ciotek, które tworzą odrębne kobiece kręgi korespondencyjne. Ich powstawanie świadczy nie tylko o silnych więziach rodzinnych, ale także bardzo istotnej roli społecznej kobiet w aspekcie edukacyjno-wychowawczym. Ta rola wzrastała niepomiernie w odniesieniu do wdów, na barki których spadały obowiązki zorganizowania i sfinansowania podróży edukacyjnych swoich synów lub bliskich krewnych ${ }^{41}$. W istocie kolejne listy Franciszka do obydwojga rodziców powtarzają najważniejsze bieżące kwestie podnoszone w związku z podróżami zagranicznymi. Różnią się natomiast jednym istotnym szczegółem - językiem, w którym zostały spisane. Wiele listów kierowanych do matki Franciszek napisał po francusku, a do ojca po polsku. Oprócz stałego podkreślania miłości i przywiązania do rodziców listy miały być też czytelnym dowodem postępów w nauce języka francuskiego. Franciszek tłumaczył się czasami z używania w listach ojczystej mowy niedostatecznym opanowaniem języka obcego ${ }^{42}$.

Gorący temperament Kazimierza Rzewuskiego, podróżującego po Europie w latach 1766-1768, i jego krnąbrność w odniesieniu do

40 ANK, oddział na Wawelu, APodh., I 104, s. 13; zapis wydatków Seweryna Rzewuskiego w Wersalu latem 1760 r.

41 Na ten temat zob. na przykładzie innej polskiej magnatki: J. Pietrzak, Korespondencja Katarzyny z Sobieskich Radziwittowej (1634-1694) jako źródto do poznania jej relacji rodzinnych, w: Kobiece kręgi korespondencyjne w XVII-XIX wieku, red. B. Popiołek, U. Kicińska, A. Słaby, Warszawa 2016, s. 13-30.

42 „Listy JWMWM Pani Dobrodzikiej piunktualnie mię dochodzą, jako też i ostatni 13 marca pisany z ucałowaniem rąk Macierzyńskich odebrałem, na któren nie przychodzi mi po francuski odpisać, gdyż radbym się na ten list JWMWM Pani Dobrodzikiej doskonale wyeksplikować”; CDIAUL, F. 181, op. 2, 448, k. 48: Franciszek Rzewuski do matki, Paryż, 20 IV 1747. 
sprawującego nad nim pieczę pijarskiego duchownego Aleksego Ożgi spowodowały konieczność wyznaczenia nowego opiekuna, którym został jego najstarszy, najbardziej doświadczony i ustosunkowany w kraju brat, Franciszek. W efekcie dalszy przebieg podróży, już po dołączeniu Franciszka, znamy wyłącznie z jego listów do rodziców ${ }^{43}$. Perypetie podróżne Kazimierza sprawiły, że korespondencja z jego wojażu edukacyjnego miała nieco inny charakter niż w przypadku jego starszych braci. Nieznane pozostają listy samego podróżnika do rodziców ani listy jego guwernera. Tematyka tej korespondencji ogniskuje się niezmiennie wokół obrony Kazimierza oraz notorycznych prób tłumaczenia jego nagannego zachowania przez Franciszka i wskazywania konieczności kontynuowania tej podróży mimo ewidentnie odmiennego zdania ich ojca w tej kwestii.

\section{Krąg edukacyjno-wychowawczy}

Nie mniej ważny jest też wymiar edukacyjny, związany z osiąganiem założonych celów wyjazdu zagranicznego, powodujący samorzutne wyłonienie się kręgów korespondencyjnych skupionych wokół kwestii edukacyjno-wychowawczych. Stąd ważną rolę odgrywają tutaj osoby guwernerów, odpowiadających w praktyce za jakość wykształcenia swoich podopiecznych oraz nadzór nad procesem ich wychowania, co nie mogłoby dobrze funkcjonować bez kontaktu opiekunów z guwernerami.

W odniesieniu do Rzewuskich z linii na Podhorcach wspólnym mianownikiem łączącym obie podróże edukacyjne młodych magnatów - Seweryna Józefa i Wacława - jest osoba guwernera. Z zachowanej korespondencji wynika, że kontakty z synami przebywającymi w podróży edukacyjnej odbywały się dwutorowo. Z jednej strony Stanisław Mateusz Rzewuski kontaktował się bezpośrednio ze swoimi synami, adresując do nich swoje listy, z drugiej utrzymywał stały kontakt z guwernerem - szlachcicem z Wielkopolski Marcinem Kawieckim herbu Wyssogota (1677-ok. 1751) ${ }^{44}$. Można

43 Listy znajdują się w zespole: CDIAUL, F. 181, op. 2, 447.

44 Szerzej o jego działalności politycznej, wojskowej i edukacyjnej w: A. Kucharski, S. Roszak, A. Wieczorek, Guwernerzy Rzewuskich na Podhorcach w XVII-XVIII wieku..., s. 158. 
przypuszczać, że wybór Kawieckiego na preceptora synów hetmana nie był przypadkowy, ponieważ na krótko przed wyjazdem w podróż z Sewerynem Józefem przebywał on już za granicą. Jak wynika z relacji podróżnej Felicjana Junoszy Piaskowskiego, w 1718 r. Marcin Kawiecki był w gronie towarzyszących mu osób w Paryżu ${ }^{45}$. Poza tym jeszcze jeden dokument może potwierdzać jego doświadczenia w sprawowaniu wcześniej opieki nad peregrynantem. Na potrzeby wyjazdu Seweryna Józefa za granicę Kawiecki opracował wspomnianą już instrukcję podróżna, w której mając śmiałość w wyrażaniu swoich sugestii i korzystając z doświadczenia, „będąc na podobnych funkcyjach”, zalecał wybór Paryża jako miejsca edukacji ${ }^{46}$. Warto podkreślić, że na szczególną analizę korespondencji pozwala zwarty zbiór listów pisanych przez Kawieckiego do Stanisława Mateusza Rzewuskiego z podróży edukacyjnej Seweryna Józefa, gdyż w odniesieniu do podróży edukacyjnej Wacława nie dysponujemy listami podróżnymi z okresu, kiedy peregrynant odbywał wojaże po Europie w latach 1724-1727. Pierwszy z listów, jaki posiadamy, został napisany jeszcze z Warszawy (3 października 1720 r.), a więc zanim podróżni opuścili Rzeczpospolitą. W liście tym Kawiecki, przyjmując odpowiedzialność sprawowania opieki w czasie podróży nad starszym synem hetmana, już w pierwszych słowach zobowiązuje się „odebranego Jmć Pana Starostę z rąk ojcowskich [...] na ukontentowanie Jego zupełne da Bóg do ojczyzny odprowadzić” ${ }^{47}$. Niewątpliwie powtórny angaż Kawieckiego na guwernera w czasie podróży edukacyjnej drugiego syna hetmana był wynikiem jego dotychczasowej, jak należy sądzić na podstawie korespondencji, dobrej współpracy z domem hetmańskim. Z materiału epistolograficznego jasno wynika, że Stanisław Mateusz Rzewuski miał ogromne zaufanie do guwernera, ceniąc jego lojalność oraz doświadczenie. Zresztą to zaufanie, jakim hetman darzył Kawieckiego, powierzając mu swoich synów aż w dwóch peregrynacjach, znalazło potwierdzenie już

45 Pamiętnik Felicyana Junoszy Piaskowskiego podstolego podlaskiego, majora J. K. Mości począwszy od roku 1690, Lwów 1865, s. 71.

46 Refleksyje do przysztej peregrynacyi Jmć Pana starosty chetmskiego..., s. 26. Więcej o tej instrukcji zob. M. Kawiecki, Refleksje do przysztej peregrynacji Jmć Pana starosty chetmskiego (ok. 1720), oprac. A. Markiewicz, w: Przestrogi i nauki dla dzieci..., s. 19-24.

47 LNNBU, rps 1311, f. 5, op. 1, k. 175: Marcin Kawiecki do Stanisława Mateusza Rzewuskiego, Warszawa, 3 X 1720. 
w 1728 r., kiedy Wielkopolanin został preceptorem Janusza Aleksandra Sanguszki - syna księcia Pawła Karola i Marianny z Lubomirskich ${ }^{48}$.

Poza tym znaczącą rolę w utrzymaniu kontaktu korespondencyjnego z domem rodzinnym podhoreckich Rzewuskich odgrywał rektor kolegium w Dąbrowicy oraz kapelan nadworny Stanisława Mateusza Rzewuskiego - pijar Jan Damascen Kaliński ${ }^{49}$. Jego opinia wyrażana w listach miała niejednokrotnie charakter głosu doradczego, przypominającego o osiągnięciu celu stawianego przed Sewerynem Józefem i Wacławem w czasie podróży po Europie Zachodniej i ugruntowującego w przekonaniu o jego słuszności ${ }^{50}$.

W przypadku podróży synów Wacława Rzewuskiego na bardziej szczegółową analizę korespondencji pozwala jedynie zwarty zbiór listów pisanych przez ich guwernera, które ten adresował do swego chlebodawcy. Caraccioli pisywał je do Wacława Rzewuskiego zarówno jeszcze przed wyjazdem z Polski (1755), w trakcie podróży, jak również już po powrocie do kraju (1761), zdając raporty z wykonywania swych obowiązków ${ }^{51}$. Z innych źródeł wiemy, że jego pracodawca wysoko oceniał jego kompetencje zawodowe i edukacyjne. Z tonu instrukcji podróżnej napisanej przez Wacława Rzewuskiego dla syna Józefa w 1755 r. przebija bowiem ewidentne zaufanie do lojalności i umiejętności tego guwernera. Wedle słów Wacława Rzewuskiego Caraccioli powinien być traktowany przez synów z wielkim szacunkiem i całkowitym posłuchem wobec jego poleceń. Tak silne przekonanie o wiarygodności tego preceptora musiało zaowocować polecaniem jego usług innym magnatom poszukującym właściwego wychowawcy dla swoich synów bądź podopiecznych. Niewątpliwie skutkiem takich rekomendacji było to, że Caraccioli prawie niezwłocznie po odstawieniu podopiecznego do kraju został opiekunem innego młodego magnata w jego

${ }^{48}$ M. Chachaj, op. cit., s. 170. O podróżach Sanguszków zob. A. Jakuboszczak, O zagranicznych podróżach Janusza Modesta Sanguszki, w: Polski „Grand Tour”..., s. 65-80.

49 A. Boniecki, Herbarz polski, t. 9, Warszawa 1906, s. 160.

50 Wystarczy wskazać na listy: BK PAN, rps 423, k. 166v-167: Damascen do Seweryna Józefa Rzewuskiego, [s.l.] [s.a.]; BCzart., rps 562 IV, s. 419-420: Damascen do Wacława Rzewuskiego, Luboml, 23 VIII 1726.

51 ANK, oddział na Wawelu, APodh., IV/LXIX, nr 40-48, 79-80; ANK, oddział na Wawelu, APodh., I 1/48d. 
podróży do Francji ${ }^{52}$. Zamieszczenie takiej informacji w Kronice Podhoreckiej, opisującej dzieje rodziny Rzewuskich w kolejnych pokoleniach, niewątpliwie sugeruje nieprzypadkowość tego faktu i zależność tej decyzji od dobrej opinii, którą Caraccioli uzyskał od Wacława Rzewuskiego.

Przy okazji omawiania podróży edukacyjnych Rzewuskich z Rozdołu nie sposób pominąć wymiany listów prowadzonej ze Stanisławem Konarskim, znanym pijarskim reformatorem szkolnictwa. Jako uznany autorytet edukacyjny, założyciel Collegium Nobilium i prominentny członek zakonu pijarów był proszony o konsultacje i pomoc w znalezieniu odpowiedniego guwernera dla Kazimierza Rzewuskiego ${ }^{53}$. Zapewne w tym celu wykorzystano wcześniejsze bliskie kontakty z tym zakonnikiem, ponieważ wracał on z Paryża do kraju wspólnie z Franciszkiem Rzewuskim w 1748 r.

\section{Kręgi urzędniczo-dygnitarskie}

Należy też odnotować istnienie kręgów skupionych wokół wysokich urzędników i dygnitarzy. W tym gronie sytuował się też hetman polny, a później wielki koronny Stanisław Mateusz Rzewuski jako centrum kręgu. Co więcej, warto wskazać specyficzny powód segregacji korespondencji w odniesieniu do sporządzania kopii jego listów z lat 20. XVIII w. Można stwierdzić, że do wielokrotnego powielania wybierano listy, posługując się kluczem piastowania wysokich urzędów przez nadawców i adresatów. Z tej przyczyny, nieznane nam w oryginałach, listy Stanisława Mateusza, m.in. z napomnieniami do synów bawiących za granicą, zachowały się w kilku różnych kopiariuszach.

Stanisław Mateusz Rzewuski utworzył wokół peregrynacji swoich synów krąg osób, które uczestniczyły bezpośrednio w wymianie informacji, były wsparciem dla młodzieńców, a zarazem gwarantowały pomyślną realizację wyznaczonego przez hetmana kierunku edukacji. Ze względu jednak

52 Został wówczas guwernerem jednego z Tarłów w drodze do Francji i w Paryżu; L. Rzewuski, Kronika podhorecka 1706-1779, Kraków 1860, s. 203.

53 CDIAUL, F. 181, op. 2, 526, k. 5: Stanisław Konarski do Michała Józefa Rzewuskiego, Białystok, 12 V 1766. 
na wspomniany już deficyt korespondencji podróżnej młodszego syna hetmana - Wacława, szczegółową analizę umożliwia jedynie materiał epistolograficzny z podróży starszego syna. W kręgu korespondencyjnym znalazł się stolnik rzeczycki Gabriel Piotr Neronowicz Szpillowski ${ }^{54}$, który w zastępstwie hetmana, na jego prośbę, utrzymywał kontakt listowny z Sewerynem Józefem Rzewuskim i Marcinem Kawieckim. Aktualnie dysponujemy jednym listem adresowanym do Marcina Kawieckiego. Jego tematykę stanowią głównie kwestie dotyczące prośby o nawiązanie kontaktu korespondencyjnego z ministrem saskim Jakubem Henrykiem Flemmingiem oraz sprowadzeniem kuchmistrza ze stolicy Francji, który zgodnie z życzeniem Stanisława Mateusza ma „przewyższyć wszystkich tych, których Polska ma z Paryża”"55.

Przy okazji prezentacji podróży edukacyjnych Rzewuskich na Podhorcach nie sposób nie wspomnieć o wymianie listów z osobą, która obok Kawieckiego towarzyszyła starszemu synowi hetmana w podróży zaraz po opuszczeniu domu rodzinnego. Dużą wartość w odtworzeniu przebiegu pierwszych dni podróży edukacyjnej Seweryna Józefa Rzewuskiego w 1720 r. mają listy pułkownika Jana Joachima Kampenhausena ${ }^{56}$. Warto w tym miejscu dodać, że w 1737 r. Kampenhausen był wymieniony wśród pułkowników ósmego regimentu pieszego buławy polnej koronnej. W przeszłości, tj. w latach 1706-1726, szefem regimentu był Stanisław Mateusz Rzewuski ${ }^{57}$. Z pewnością panowie znali się wcześniej i łączyły ich bliskie kontakty, skoro Kampenhausen, obok Kawieckiego, uczestniczył we wszystkich spotkaniach Seweryna Józefa przewidzianych w czasie pobytu w Warszawie. Aktualnie dysponujemy trzema listami napisanymi na przełomie września i października 1720 r., a zatem z okresu, kiedy podróżnicy

54 A. Haratym, Szpillowski Neronowicz Gabriel Piotr h. Ostrogski, w: PSB, t. 48, red. A. Romanowski, Warszawa-Kraków 2012-2013, s. 633-634.

55 BCzart., rps 2171 IV, s. 50: Gabriel Piotr Neronowicz Szpillowski do Marcina Kawieckiego, [s.l.] 11 III 1722.

56 J. Gierowski, Kampenhausen Jan Joachim h. wtasnego, w: PSB, t. 11, red. Z. Alberowa, E. Rostworowski, Wrocław-Warszawa-Kraków 1964-1965, s. 590-592. Więcej na temat jego kariery politycznej w: A. Boniecki, op. cit., s. 219.

57 B. Gembarzewski, Rodowody putków polskich i oddziatów równorzędnych od r. 1717 do r. 1831, Warszawa 1925, s. 29. 
nie opuścili jeszcze kraju i przebywali w Warszawie - dwoma listami Kampenhausena adresowanymi do Stanisława Mateusza Rzewuskiego i jednym listem hetmana zaadresowanym do pułkownika. Tematyka listów adresowanych do hetmana oscyluje głównie wokół spotkań Seweryna Józefa w Warszawie, m.in. z kanclerzem Janem Sebastianem Szembekiem, a także dyskusji dotyczącej pobytu peregrynanta za granicą, prowadzonej w duchu rad i ostrzeżeńn ${ }^{58}$. W liście adresowanym do Jana Kampenhausena hetman licząc, że korespondencja zastanie podróżników jeszcze w Warszawie przed wyjazdem do Wrocławia - prosi z kolei pułkownika o przypominanie synowi jego instrukcji oraz zwrócenie mu uwagi na posłuszeństwo wobec Kawieckiego ${ }^{59}$.

Jak już wiemy z listów wymienianych między Szpillowskim a Kawieckim, w tym kręgu korespondencyjnym pojawia się jeszcze jedna osoba wspomniany już minister saski Jakub Henryk Flemming. Próbując scharakteryzować krąg korespondentów Seweryna Józefa Rzewuskiego, trzeba przywołać listy, jakie odbierał w czasie pobytu w Warszawie w 1720 r. z rąk ministra saskiego, zaadresowane do przedstawicieli dworów europejskich. Jest to niezwykle ważna informacja, ponieważ tym sposobem korespondencja umożliwiała Sewerynowi Józefowi spotkania z przedstawicielami dworów saskiego, berlińskiego, angielskiego, a także francuskiego, co niewątpliwie świadczy o randze rodziny Rzewuskich w kręgach towarzyskich i politycznych w Rzeczypospolitej oraz poza jej granicami. Poza tym nie były to jedyne pisma uwierzytelniające, jakie znalazły się w jego posiadaniu. Seweryn Józef wspomina jeszcze o odebraniu z Warszawy listu od generała Stanisława Poniatowskiego, który był adresowany do lorda kanclerza - Tomasza Parkera - króla angielskiego Jerzego ${ }^{60}$.

58 LNNBU, rps 1311, f. 5, op. 1, k. 173-173v: Jan Kampenhausen do Stanisława Mateusza Rzewuskiego, Warszawa, 1 X 1720; LNNBU, rps 1311, f. 5, op. 1, k. 174: Jan Kampenhausen do Stanisława Mateusza Rzewuskiego, Warszawa, 3 X 1720.

59 APL, rps 93, nlb.: Stanisław Mateusz Rzewuski do pułkownika Jana Kampenhausena, Łukówek, 27 IX 1720.

60 LNNBU, rps 1311, f. 5, op. 1, k. 174v: Seweryn Józef Rzewuski do Stanisława Mateusza Rzewuskiego, Warszawa [s.a.]; zob. A. Wieczorek, op. cit., s. 159. 
Przy okazji prezentowania podróży edukacyjnej Seweryna Józefa Rzewuskiego nie sposób pominąć okoliczności nawiązania kontaktu listownego z ministrem saskim. W czasie pobytu za granicą głównym motywem do wznowienia relacji z Flemmingiem było wydarzenie, do jakiego doszło w Brukseli. W istocie ojciec był bardzo zaniepokojony sytuacją, w której znalazł się jego syn w czasie podróży po Europie - chodziło mianowicie o zatrzymanie 1000 talarów w czasie pobytu w Brukseli. Bez wątpienia sprawa brukselska przyczyniła się do uruchomienia wielu kontaktów. W oczekiwaniu na jej wyjaśnienie i rozwiązanie Stanisław Mateusz Rzewuski sam kontaktował się z kanclerzem Szembekiem i Flemmingiem oraz wielokrotnie ponaglał syna do nawiązania kontaktu z ministrem, widząc w tym jedyny sposób pomyślnego zakończenia ${ }^{61}$. Co istotne, nie kto inny, lecz właśnie Seweryn Józef miał zaadresować korespondencję do ministra saskiego, włączając się w ten sposób w orbitę korespondentów z ministrem saskim. Sprawa brukselska towarzyszyła Sewerynowi Józefowi przez cały okres podróży, co w konsekwencji prowadziło do poszerzania kręgu korespondencyjnego osób, które mogły pomóc w jej pozytywnym rozwiązaniu. Stanisław Mateusz Rzewuski napisał o niej nawet do kardynała Melchiora de Polignaca, prosząc starszego syna o przekazanie mu listu osobiście ${ }^{62}$. I nie była to ostatnia osoba zaangażowana w tę sprawę. Jeszcze w ostatnim roku podróży Seweryna Józefa został w nią wprowadzony książę Eugeniusz Sabaudzki. Świadczy o tym kopia odpowiedzi księcia do rezydenta cesarza w Rzeczypospolitej - Franciszka Martelsa, przesłana przez hetmana w liście do Kawieckiego ${ }^{63}$.

Patrząc na podróże edukacyjne podhoreckich Rzewuskich z perspektywy kręgów korespondencyjnych, trzeba wspomnieć, w odniesieniu

61 BCzart., rps 558 IV, s. 378: Stanisław Mateusz Rzewuski do Marcina Kawieckiego, Nowosiółki, 17 X 1721. Szerzej na temat zdarzenia zob. A. Wieczorek, op. cit., s. 173-175 .

62 BCzart., rps 558 IV, s. 459: Stanisław Mateusz Rzewuski do Marcina Kawieckiego, Luboml, 26 XII 1721.

63 BCzart., rps 558 IV, s. 656: Stanisław Mateusz Rzewuski do Seweryna Józefa Rzewuskiego, [s.l.] 8 I 1723. Franciszek Martels rezydentem cesarskim został w 1715 r.; zob. J. Gierowski, $Z$ dziejów handlu Wroctawia z Polska w dobie saskiej, „Śląski Kwartalnik Historyczny Sobótka” 1949, R. 4, s. 195. 
do podróży edukacyjnej Seweryna Józefa, że ta wymiana korespondencji umożliwiała również podróżującemu kontakt z posłem Saksonii w Paryżu, później ambasadorem króla Augusta II we Francji - Karolem Henrykiem von Hoymem, który pośredniczył w przekazywaniu listów z domu rodzinnego. Osobiście od niego odbierał je Kawiecki ${ }^{64}$. W przekazywanie weksli z Warszawy do Paryża zaangażowany był natomiast dyplomata francuski Jan Wiktor de Besenval ${ }^{65}$.

Warto jeszcze wskazać na materiał epistolograficzny z kręgu korespondencyjnego wojewody krakowskiego Janusza Antoniego Korybuta Wiśniowieckiego. Bezpośrednio z podróżą edukacyjną wiąże się bowiem list pożegnalny Seweryna Józefa Rzewuskiego adresowany do wojewody krakowskiego jeszcze z Warszawy pod koniec września 1720 r., na krótko przed „paryską drogą" ${ }^{66}$. Zresztą do nawiązywania kontaktu z wojewodą krakowskim Wiśniowieckim, a także kasztelanem krakowskim Adamem Mikołajem Sieniawskim w czasie podróży zachęcał sam hetman, prosząc Seweryna Józefa, aby zadbał o relacje z nimi, utrzymując kontakt listowny ${ }^{67}$.

Jak już nadmieniono, w odniesieniu do Rzewuskich z linii na Rozdole kręgi korespondencyjne wyznaczają zasięg sieci powiązań i kontaktów od lat 40. do początku 60. XVIII w. Za granicę wyjeżdżali wówczas w celach edukacyjnych synowie Michała Józefa, czyli ówczesnej głowy tej linii magnackiej. Kręgi te miały nie tylko rodzinne uwarunkowania, ale także specyficzne znaczenie towarzyskie i polityczne. Franciszek Rzewuski kilkakroć wspominał o legitymowaniu się listami uwierzytelniającymi, których wystawcami byli najwyżsi urzędnicy państwa polsko-saskiego. Potwierdza to wysoką rangę jego rodziny na dworze królewskim i w Warszawie, i w Dreźnie. Podczas pobytu we Włoszech to właśnie listy kredencjalne

${ }^{64}$ LNNBU, rps 1311, f. 5, op. 1, k. 177: Marcin Kawiecki do Stanisława Mateusza Rzewuskiego, Paryż, 17 III 1721.

${ }_{65}$ BCzart., rps 558 IV, s. 520: Stanisław Mateusz Rzewuski do Marcina Kawieckiego, Luboml, 27 II 1722.

${ }^{66}$ APL, rps 93, nlb.: Seweryn Józef Rzewuski do Janusza Wiśniowieckiego, Warszawa, IX 1720.

${ }^{67}$ BCzart., rps 558 IV, s. 492: Stanisław Mateusz Rzewuski do Seweryna Józefa Rzewuskiego, Luboml, 30 I 1722. 
otworzyły mu dostęp do posła Saksonii oraz możliwość audiencji u Marii Amalii Wettyn, królowej Neapolu ${ }^{68}$. Wymienieni przez Franciszka wystawcy listów, Henryk Brühl oraz hrabia Józef Gabelon Wackerbarth-Salmour, byli wówczas u szczytu swej kariery politycznej, a Brühl w 1746 r. został pierwszym ministrem Saksonii ${ }^{69}$. Zabiegi polityczne Wacława Rzewuskiego powodowały również konieczność utrzymywania korespondencji z dyplomatami innych państw. Wskutek tego młody Seweryn stał się jego zagranicznym emisariuszem mającym przekazać list od ojca rosyjskiemu posłowi nadzwyczajnemu w Rzeczypospolitej Hermanowi Karlowi von Keyserlingowi podczas osobistego spotkania w Wiedniu w 1759 r. $^{70}$

Listy kierowane do przyjaciół rodziny nadawcy pozwalały też na szukanie protekcji wysokich urzędników, przydatnej w planowaniu dalszej kariery po powrocie do kraju, projektach mariaży bądź nadziei na zyskanie urzędów i dóbr. Taki przede wszystkim charakter miało adresowanie listów do Jana Tarły, podstolego litewskiego, wojewody sandomierskiego i lubelskiego w jednej osobie, przez trzech synów Michała Józefa Rzewuskiego: Franciszka, Adama i Jana w drugiej połowie lat 40. XVIII w. Symptomatyczne w tym wypadku jest to, że nie istniały żadne realne więzy pokrewieństwa między nimi. Głównym motywem pisania tych listów była swego rodzaju mentalność klientalna każąca szukać możliwości poparcia u wysokiego urzędnika państwowego i opieki patrona dla budowania własnej pozycji ${ }^{71}$. Dodajmy też do tego, że Tarło nie dość, że był bogaty, to dodatkowo nie miał żadnego potomka ${ }^{72}$. Jednak pojęcia klientelizmu nie należy tutaj oczywiście rozumieć dosłownie, gdyż obydwie strony należały przecież do elity magnackiej.

68 CDIAUL, F. 181, op. 2, 448, k. 8: Franciszek Rzewuski do matki, Neapol, $7 \mathrm{~V} 1746$.

69 J. Staszewski, August III Sas, Wrocław 2010, s. 228.

70 W. P. Rzewuski, Instrukcje zwiąane z edukacja syna Seweryna w Warszawie $i$ za granica (1754 i 1759), oprac. A. Kucharski, w: Przestrogi i nauki dla dzieci..., s. 160.

71 O klientelizmie zob. A. Mączak, Klientela. Nieformalne systemy wtadzy $w$ Polsce i Europie XVI-XVIII w., Warszawa 2000.

72 U. Kosińska, Tarto Jan h. Topór, w: PSB, t. 52, red. A. Romanowski, Warszawa 2018, s. 296. 
Brak inicjałów imion w podpisach autorów listów do Jana Tarły znacznie utrudnia ich identyfikację zawartą powyżej. Dlatego fakt ten wymaga bliższego wyjaśnienia. Tylko jeden z podróżników podpisywał się pełną formą imienia. Był to Adam Rzewuski. Obok niego możemy wyróżnić jeszcze co najmniej dwóch nadawców. Analiza charakteru pisma oraz stylu wypowiedzi sugeruje, że jednym z nich był najstarszy z grona braci Franciszek Rzewuski. Potwierdza to także zgodność dat i miejsc pobytu, z których wysyłał swoje listy razem z korespondencją kierowaną do matki ${ }^{73}$. Listy były nadawane m.in. z Turynu ${ }^{74}$, gdzie oglądano gmachy akademii rycerskiej, w której studiowali też wówczas inni Polacy. Trzeci z młodych Rzewuskich ukrywa się pod inicjałem J., co zapewne wskazuje na Jana Rzewuskiego, którego znany heraldyk Kacper Niesiecki określał mianem młodzieńca „wielkich nadziei i przymiotów”75. Wśród listów kierowanych do Tarły znajduje się też jeden adresowany do ojca podróżników. Trafił tam zapewne w wyniku specyficznej metody doręczania korespondencji podróżnej, o której wspominał Franciszek, informując, że wraz z listami do rodziców wysyła także w tej samej kopercie list do Jana Tarły ${ }^{76}$. W ten sam sposób zapewne jeden z listów do ojca doręczono Janowi Tarle. Przy czym innym razem Franciszek wyrażał zdziwienie, że listy wysłane przez niego do Tarły, łącznie z korespondencją do rodziców („inkludowane w tejże samej kopercie”), miałyby zaginąć na poczcie i nie dotrzeć do rąk tego adresata, podczas gdy listy do rodziców docierały ${ }^{77}$. Należy tu zaznaczyć, że poza sekretną i często szyfrowaną korespondencją dyplomatyczną wgląd do listów prywatnych, szczególnie w kręgu rodziny i znajomych, był w epoce

73 Dla przykładu tego samego dnia wysłał list do obydwojga tych adresatów z Rzymu 2 lipca 1746 r.; CDIAUK, F. 254, op. 1, 531, k. 48-48v.

74 Listy wysyłało dwóch różnych Rzewuskich, Adam i zapewne Jan, w marcu i kwietniu 1749 r.; CDIAUK, F. 254, op. 1, 531, k. 69-71v.

75 K. Niesiecki, Herbarz polski, t. 8, Lipsk 1841, s. 225.

76 CDIAUL, F. 181, op. 2, 448, k. 14v: Franciszek Rzewuski do matki, Rzym, 2 VII 1746.

77 CDIAUK, F. 254, op. 1, 531, k. 52: Franciszek Rzewuski do Jana Tarły, Paryż, 10 II 1747. 
nowożytnej tolerowany, a niekiedy nawet wskazany ${ }^{78}$. Jak widać, był to też często praktykowany sposób na pewne doręczenie listów. W dedykacjach listów adresowanych do Tarły uwidacznia się podkreślanie familiarnego stosunku podróżujących nadawców do adresata. Nie miał on jednak żadnego uzasadnienia w rzeczywistym pokrewieństwie. Jan Tarło jest tam tytułowany jako „Kochany Dziad”, a młodzi Rzewuscy określają samych siebie mianem synowców i wnuków. Dość niecodzienna forma tej tytulatury jest spowodowana nie tylko konwencją epistolarną. Nie mniej istotnym faktem wydaje się właśnie interesowność młodych Rzewuskich przewijająca się w stylu ich narracji i stosowanej tytulaturze. W jednym z listów mówi się wprost o liczeniu na protekcję Tarły i zawiedzionych oczekiwaniach na poparcie przez ojca.

Wśród adresatów listów Franciszka Rzewuskiego było też wielu urzędników wyższego i średniego szczebla, np. pisarz wielki koronny (duchowny) Władysław Antoni Łubieński, scholastyk krakowski, a później arcybiskup lwowski. Z niektórymi urzędnikami, adresatami jego listów, łączyły go więzy dość bliskiego pokrewieństwa, np. z Sewerynem Józefem Rzewuskim z linii na Podhorcach, sprawującym wówczas urząd świeckiego referendarza wielkiego koronnego.

\section{Krąg towarzyski}

$\mathrm{Na}$ tle zgromadzonej korespondencji z lat 20. XVIII w. wyróżnia się materiał epistolograficzny (co prawda aktualnie dysponujemy tylko jednym listem) z kręgu korespondencyjnego Radziwiłłów, który jest przechowywany w zespole Archiwum Radziwiłłów Archiwum Głównego Akt Dawnych w Warszawie (nr 13655). Po pierwsze - co istotne, jeśli idzie o zachowany materiał - jest jedynym oryginalnym listem Seweryna Józefa Rzewuskiego z pierwszych miesięcy podróży edukacyjnej, pisanym w momencie opuszczania Rzeczypospolitej, a zatem adresowanym już z Wrocławia 20 października 1720 r. Po drugie, został on zaadresowany do przyjaciela, co poszerza

78 M. Jarczykowa, Czytelniczy obieg korespondencji staropolskiej, w: Epistolografia w dawnej Rzeczypospolitej, t. 1, red. P. Borek, M. Olma, Kraków 2011, s. 382. 
krąg korespondencyjny o grupę rówieśniczą Seweryna Józefa. Można założyć, że adresatem był Michał Kazimierz Radziwiłł „Rybeńko” - wówczas 18-letni młodzieniec, który niebawem sam uda się w podró $\dot{z}^{79}$. Ordynatem kleckim był wtedy wprawdzie Jan Mikołaj Radziwiłł, ale z racji wieku (miał wówczas 39 lat) trudno domniemywać, aby był przez młodego Rzewuskiego nazwany przyjacielem ${ }^{80}$. List może świadczyć o podtrzymaniu kontaktu z przyjacielem, z którym nie udało się Sewerynowi Józefowi spotkać przed wyjazdem do Wrocławia, a tym samym się pożegnać: „Że go zaś przytomnie pożegnać i uściskać nie mogę, zostawuję te kilka linii in pignus" ${ }^{" 1}$.

\section{Krąg pośredników}

Ten krąg zamyka się w głównej mierze w sferze nawiązywania i podtrzymywania listownych kontaktów niezbędnych do właściwego przebiegu podróży oraz jej obsługi pocztowej i finansowej. Można do niego zaliczyć spedytorów pośredniczących $\mathrm{w}$ wysyłaniu i odbieraniu korespondencji oraz bankierów. Szczególnie ta ostatnia kategoria pośredników była niezwykle ważna, o czym świadczą stałe narzekania na brak pieniędzy, ciągle powracająca konieczność spłaty wierzytelności czy zaciągania nowych pożyczek w oczekiwaniu na dopływ gotówki z kraju ${ }^{82}$.

W omawianym okresie należy zwrócić uwagę na kontakty tego typu istniejące w czasie podróży Rzewuskich na Podhorcach w latach 20. XVIII w. W kręgu pośredników znalazł się kupiec i bankier warszawski - Piotr

79 Zob. Podróże litewskiego magnata do Gdañska, Cztuchowa, a nawet i dalej... Fragmenty "diariusza” Michata Kazimierza Radziwitta „Rybeńki” z lat 1721, 1737 i 1752, wyd. J. Dygdała, Warszawa 2013.

${ }_{80}$ A. Rachuba, Radziwitt Jan Mikotaj Aleksander h. Trąby, w: PSB, t. 30, red. E. Rostworowski, Wrocław-Warszawa-Kraków-Gdańsk-Łódź 1987, s. 199-202.

${ }^{81}$ AGAD, AR, dz. V, nr 13655: Seweryn Józef Rzewuski do przyjaciela, Wrocław, 20 X 1720.

${ }^{82}$ Szerzej na ten temat zob. rozdział Podróżni i bankierzy, w: A. Mączak, Życie codzienne w podróżach po Europie w XVI i XVII w., Warszawa 1980, s. 107-112. 
Riaucour, który na prośbę Stanisława Mateusza Rzewuskiego wysyłał weksle z Warszawy do podróżujących po Europie synów hetmana ${ }^{83}$.

Wiadomo też, że w czasie podróży Franciszka Rzewuskiego po Włoszech rezydujący w Rzymie ksiądz Barszczewski odpowiadał za pośrednictwo w przekazywaniu jego listów i transferze informacji. Przebywając we Włoszech oraz we Francji, Franciszek korzystał także z pomocy dwóch zakonów: teatynów oraz misjonarzy, wspominając przy tej okazji znaną postać księdza Piotra Hiacynta Śliwickiego. Duże znaczenie mogły mieć w tym względzie dawne znajomości, gdyż wiadomo, że w warszawskim kolegium teatynów kształcili się Rzewuscy z Podhorców. Co do Franciszka takiej pewności nie ma. Niemniej popadł w konflikt z rzymskimi teatynami, którzy donosili matce listownie o jego wątpliwej konduicie. Podróżnik, tłumacząc te zarzuty, rewanżował się im, oskarżając ich o zdzierstwo i polecanie drogich kwater ${ }^{84}$.

W wymianie jego korespondencji aktywnie pośredniczyli też wówczas bankierzy. Krótko po przybyciu do Francji młodzieniec powiadamiał bowiem o odebraniu listów od bankiera w Lyonie ${ }^{85}$. Kiedy przebywał z kolei później w Paryżu, odbierał je od innego bankiera, niejakiego Marsettiego, oraz korespondenta Noela. Sprawne finansowanie podróży było zapewnione przede wszystkim przez wystawianie wiarygodnych weksli. Franciszkowi zapewniał to m.in. czołowy warszawski kupiec i bankier Piotr Tepper Starszy. Osiągnął on nieco później dominującą pozycję w kraju, stając się najpotężniejszym bankierem udzielającym pożyczek Stanisławowi Augustowi i Rzeczypospolitej ${ }^{86}$. Ta współpraca nie zawsze układała się dla podróżnika korzystnie. Można nawet powziąć pewne podejrzenia co do rzetelności bankiera, ponieważ młody Rzewuski kilkakrotnie monitował o niebagatelną kwotę 500 czerwonych złotych, prosząc swoich rodziców o interwencję

83 BCzart., rps 558 IV, s. 520: Stanisław Mateusz Rzewuski do Marcina Kawieckiego, Luboml, 27 II 1722; BCzart., rps 562 IV, s. 187: Stanisław Mateusz Rzewuski do Wacława Rzewuskiego, Olesko, 16 IX 1725.

84 CDIAUL, F. 181, op. 2, 448, k. 36: Franciszek Rzewuski do matki, Paryż, 3 I 1747.

85 CDIAUL, F. 181, op. 2, 448, k. 25: Franciszek Rzewuski do matki, Lyon, 23 X 1746.

86 M. Wojtyński, Szkatuta prywatna króla Stanistawa Augusta Poniatowskiego, Warszawa 2003, s. 57, 71. 
w tej sprawie. Występowały też znaczne opóźnienia i problemy w przepływie gotówki. Weksle Teppera nie były powszechnie honorowane w Rzymie, w związku z czym podróżnik musiał go listownie prosić o wystawienie nowego dokumentu ${ }^{87}$.

\section{Kontakty z elitami intelektualnymi}

Nieco inny charakter ma obecność Rzewuskich - choć jedynie śladowa, biorąc pod uwagę ogrom całego zbioru listów - w kręgu korespondencyjnym referendarza wielkiego koronnego Józefa Andrzeja Załuskiego. Ten typ kręgu jest traktowany jako przykład kontaktów epistolograficznych z elitami intelektualnymi. Wśród korespondentów Załuskiego odnotowujemy głowy obydwu linii rodziny Rzewuskich w czasach saskich. Największą podaż listów zapewniają Wacław oraz Józef Michał Rzewuscy ${ }^{88}$. Jednak bezpośrednio z podróżami ich synów wiąże się jedynie kilka listów wysłanych przez guwernerów młodych Rzewuskich z linii na Rozdole i Podhorcach. To mianowicie Jan Hildebrand ${ }^{89}$ oraz Louis-Antoine Caraccioli, którzy adresowali listy do Józefa Andrzeja Załuskiego, tworząc korespondencyjną namiastkę europejskiej rzeczypospolitej uczonych, swoistej republiki listów, w której ten typ przepływu informacji miał dominujący charakter.

Korespondencja z Załuskim mówi dużo o Caracciolim. Znany jest jego list poprzedzający wyjazd w pierwszą podróż, kiedy to opiekował się Józefem i Stanisławem, starszymi synami Wacława ${ }^{90}$. Drugi z listów został natomiast napisany już po powrocie do Polski z wojażu, podczas którego

87 CDIAUL, F. 181, op. 2, 448, k. 25v: Franciszek Rzewuski do matki, Lyon, 23 X 1746.

${ }^{88}$ Katalog rękopisów Biblioteki Narodowej, seria 2, t. 2, sygn. 3006-3300: rękopisy z Biblioteki Załuskich i innych zbiorów polskich, oprac. B. St. Kupść, K. Muszyńska, Warszawa 1980, s. 524.

89 BN, rps 3247, t. 1, k. 124-125.

90 BN, rps 3255, t. 1, k. 40-41: Louis-Antoine Caraccioli do Józefa Andrzeja Załuskiego, Podhorce, 7 VII 1755. 
towarzyszył Sewerynowi, i faktycznym zakończeniu służby u Rzewuskich ${ }^{91}$. Świetnie ilustruje on losy cudzoziemskich guwernerów, którzy opierając się na dobrej opinii, którą potrafili sobie wyrobić u swoich patronów, otrzymywali kolejne angaże, znajdując zatrudnienie na stanowiskach preceptorów w innych rodzinach magnatów lub bogatej szlachty. W ten sposób Caraccioli zapewnił sobie także powrót do Francji jako guwerner jednego z Tarłów.

Archiwalia Rzewuskich świadczą również o włączeniu tej rodziny w skład jednego z największych kręgów korespondencyjnych europejskiego oświecenia, wytworzonego wokół osoby sławnego francuskiego filozofa Woltera. Można odnotować takie formy dokumentacji kontaktów Rzewuskich z europejskim parnasem, chociaż oryginalne listy, pisane do nich przez Woltera z Monachium, pochodzą już z czasu po zakończeniu podróży edukacyjnych ${ }^{92}$.

\section{Kontakty z dworem królewskim i osobą władcy}

Zupełnie wyjątkowym przykładem kręgu korespondencyjnego, na tle zaprezentowanym powyżej, jest pozostawanie Rzewuskich w orbicie korespondentów monarszych. Ta wyjątkowość nie polega na samym istnieniu takiej korespondencji, co było oczywiste, biorąc pod uwagę magnacką kondycję społeczną Rzewuskich. W kręgu nadawców listów kierowanych do Stanisława Augusta Poniatowskiego znajdujemy Rzewuskich zarówno z Podhorców, jak i Rozdołu. I nie są to tylko pojedyncze listy, ale dość zwarty zbiór opatrzony nazwą: „Korrespondencya Jego Królewskiej Mości z familią Rzewuskich a 12 Januarii 1763 ad 18 Aprilis 1780"93. Wystarczy powiedzieć, że z okresu tych kilkunastu lat pochodzi ponad 70 listów ${ }^{94}$. Jednak Rzewuscy z obydwu linii znaleźli się w kręgu korespondencyjnym

${ }^{91}$ BN, rps 3261, t. 1, k. 44-45: Caraccioli do Józefa Andrzeja Załuskiego, Wiszniowa, 16 VII 1761.

${ }^{92}$ CDIAUK, F. 259, op. 1, spr. 97, k. 4-8v. Trzy listy Woltera są datowane na 1776 r.

93 Catalogus codicum manu scriptorum Musei Principum Czartoryski Cracoviensis, vol. 1, oprac. J. Korzeniowski, Kraków 1887-1893, s. 231.

${ }_{94}$ BCzart., rps 684 IV, s. 409-684. 
Stanisława Augusta z odmiennych powodów. Rzecz jasna główną przyczyną ich obecności w tym gronie była konieczność utrzymywania relacji z władcą oraz efekt polityki magnackiej w postaci zabiegów o królewskie łaski, urzędy, nadania czy odznaczenia. Co więcej, ujawnia się tu także inny aspekt, tak charakterystyczny dla tworzenia kręgu przez ostatniego polskiego króla, czyli budowy własnego stronnictwa politycznego ${ }^{95}$. W takim charakterze uczestniczył w tej strukturze przede wszystkim Franciszek Rzewuski, dyplomata i zaufany człowiek króla. Jego korespondencja z monarchą i jego ministrami, z okresu pełnienia misji poselskich, znajduje się między listami czołowych dyplomatów tego czasu' ${ }^{96}$.

Można pokusić się o wskazanie także istotnej różnicy. O ile linia rozdolska uczestniczyła w tym kręgu na zasadzie pozytywnych relacji z władcą, o tyle podhoreccy magnaci, Wacław i Seweryn Rzewuscy, znajdują się na przeciwległym biegunie, jako zdeklarowani opozycjoniści antykrólewscy. Aczkolwiek podróże edukacyjne w tej linii zakończyły się przed wstąpieniem Stanisława Poniatowskiego na tron. Ewenementem były natomiast kontakty z królem nawiązywane odnośnie do podróży edukacyjnych podejmowanych przez Rzewuskich z Rozdołu. Niestety listy związane z podróżami magnatów z tej linii, przynajmniej przy obecnym stanie badań, stanowią ułamkową część tej korespondencji. Znanych jest chociażby kilka listów rodziców Kazimierza Rzewuskiego pisanych w kontekście planowania i organizacji jego zagranicznego grand tour ${ }^{97}$.

\section{Zakończenie}

Oczywiście wskazane zasoby korespondencji Rzewuskich z podróży edukacyjnych są dalekie od wyczerpania zbiorów, lecz z powodzeniem mogą stanowić punkt wyjścia do prowadzenia dalszych badań. Ze względu na rozproszenie listów, występowanie pojedynczych egzemplarzy w różnorodnych

95 W. Jurkiewicz, Korespondencja elit Polski stanistawowskiej. Analiza wybranych kręgów korespondencyjnych, Bydgoszcz 1992, s. 41.

96 AGAD, Zbiór Popielów, 84; korespondencja z lat 1765-1770.

97 A. Kucharski, Blaski i cienie..., s. 69. 
zbiorach archiwalnych i bibliotecznych można przypuszczać, że wskazana baza źródłowa może jeszcze ulec rozszerzeniu. Ten stan rzeczy może się również zmienić pod względem występowania wyznaczonych powyżej kręgów korespondencyjnych, a co za tym idzie, również co do osób, które bezpośrednio uczestniczyły w podróży lub pośredniczyły w wymianie informacji, a także decydowały o prawidłowym jej przebiegu. Ich zasięg może znacznie się rozszerzyć zarówno jeśli idzie o osoby tworzące krąg korespondencyjny, jak i sam typ kręgów korespondencyjnych. Dodajmy już na koniec, że wiele udokumentowanych spostrzeżeń, a także niektóre zaledwie zasygnalizowane w tym miejscu kwestie nadal pozostają otwarte i będą przedmiotem naszych dociekań. Należy przypuszczać, że prowadzenie dalszej kwerendy zmieni ten stan rzeczy, co bez wątpienia stanowiłoby uzupełnienie brakującego materiału i podjęcie nowych wątków. 